\title{
Distribusi Frekuensi Soil Transmitted Helminth pada Sayuran Selada (Lactuca sativa) yang Dijual di Pasar Tradisional dan Pasar Modern di Kota Padang
}

Verdira Asihka, Nurhayati, Gayatri

\begin{abstract}
Abstrak
Penyakit kecacingan sampai saat ini masih merupakan masalah kesehatan di daerah tropis, termasuk Indonesia. Banyak faktor yang menyebabkan tingginya angka kejadian penyakit ini, salah satunya yaitu memakan sayuran mentah yang tidak dicuci bersih seperti selada atau kol yang sering dijadikan lalapan. Daun selada berposisi duduk sehingga dapat kontak langsung dengan tanah. Keadaan ini memungkinkan STH (Soil Transmitted Helminth) yang berada ditanah akan mudah menempel pada daun selada. Tujuan peneliti melakukan penelitian ini adalah untuk mengetahui ada atau tidaknya STH pada selada yang dijual di pasar tradisional dan modern di Kota Padang. Penelitian ini dilakukan di Laboratorium Parasitologi Fakultas Kedokteran Universitas Andalas sejak Bulan SeptemberDesember 2013. Penelitian ini berjenis deskriptif menggunakan metode sedimentasi. Hasil yang peneliti dapatkan dari penelitian ini adalah ditemukan STH positif pada 32 dari 44 sayuran selada dari pasar tradisional di Kota Padang dengan persentase $73 \%$. Tiga dari 5 sayuran selada dari pasar modern di Kota Padang dinyatakan positif dengan persentase $40 \%$. Jenis STH terbanyak yang peneliti temukan pada penelitian ini adalah telur Ascaris sp (79\%), larva Trichostrongylus orientalis (16\%) dan telur cacing tambang (5\%). Jadi, Terdapat kontaminasi STH pada selada yang dijual di pasar tradisional maupun pasar modern di Kota Padang.
\end{abstract}

Kata kunci: Soil Transmitted Helminth, sayuran selada, pasar tradisional, pasar modern

\section{Abstract}

Worm disease is still a health problem in the tropics, including Indonesia. Many factors contribute to the high incidence of this disease, one of which is eating unwashed raw vegetables such as lettuce or cabbage cleaner is often used as vegetables. Lettuce sitting position so that it can direct contact with the ground. This situation allows STH ( Soil Transmitted Helminths ) that are ground will easily stick to the leaves selada. Purposes of researchers conducted this study was to determine the presence or absence of STH on lettuce sold in traditional markets and modern in the city of Padang. This research was conducted in the Laboratory of Parasitology, Faculty of Medicine, University of Andalas since Month from September to December 2013. This study was descriptive using sedimentation method. Researchers get results of this study were found positive on STH 32 of 44 lettuce from traditional markets in the city of Padang with a percentage of $73 \%$. Three of 5 lettuce of the modern market in Padang tested positive with a percentage of $40 \%$. Most types of STH that researchers have found in this study are the eggs of Ascaris sp (79\%), Trichostrongylus orientalis larvae (16\%) and hookworm eggs (5\%). So, There STH contamination on lettuce sold in traditional markets and modern markets in Padang.

Keywords: Soil Transmitted helminths, lettuce, traditional markets, modern market

Affiliasi penulis : Fakultas Kedokteran Universita Andalas Korespondensi :Verdira Asihka, email: averdira@yahoo.com, Telp: 085274717223

\section{PENDAHULUAN}

Penyakit kecacingan sampai saat ini masih merupakan masalah kesehatan masyarakat di daerah 
tropis, terutama yang disebabkan oleh nematoda usus yang ditularkan melalui tanah atau sering disebut Soil Transmitted Helminthes (STH). ${ }^{1}$ Terdapat beberapa jenis nematoda usus yang termasuk kedalam STH yaitu cacing gelang (Ascaris lumbricoides), cacing tambang (Ancylostoma duodenale dan Necator americanus), cacing cambuk (Trichuris trichiura) dan beberapa spesies Tricostrongylus. ${ }^{2}$

Penyakit ini dapat mengakibatkan penurunan kondisi kesehatan, gizi dan produktivitas penderita sehingga secara ekonomi banyak menyebabkan kerugian, karena adanya kehilangan karbohidrat, protein dan darah yang pada akhirnya dapat menurunkan kualitas sumber daya manusia. Akibat pada anak dapat menimbulkan gangguan tumbuh kembang dan penurunan konsentrasi belajar sehingga akan mempengaruhi peran anak sebagai penerus bangsa. $^{2}$

Angka kejadian tertinggi penyakit ini terdapat pada kawasan sub-Sahara Afrika, Amerika, China dan Asia Timur. Berdasarkan laporan hasil survei prevalensi penyakit kecacingan pada 10 propinsi, didapatkan angka kecacingan nasional adalah $30,35 \%$. Sumatera Barat $(82,3 \%)$ menduduki peringkat kedua setelah Nusa Tenggara Barat $(83,6 \%){ }^{3}$ Berdasarkan data dari Departemen Parasitologi FKUI mulai 2002 - 2009 angka kejadian penyakit kecacingan berbeda-beda di setiap daerah di Indonesia dan Sumatera Barat menduduki posisi petama. ${ }^{4}$

Tingginya angka kejadian penyakit ini dipengaruhi oleh rendahnya tingkat sanitasi pribadi (perilaku hidup bersih dan sehat), seperti tidak mencuci tangan sebelum makan dan setelah BAB, tidak menjaga kebersihan kuku, BAB sembarangan seperti di pantai, sungai, dan di tengah perkebunan, ${ }^{5}$ perilaku jajan di sembarang tempat, ${ }^{6}$ serta memakan sayuran mentah yang tidak dicuci bersih seperti selada atau kol yang sering dijadikan lalapan. ${ }^{7}$

Selada merupakan sayuran yang digemari, terutama selada keriting. ${ }^{8}$ Terbukti dari selada yang mudah ditemukan pada makanan asing seperti salad, hot dog, hamburger, sandwich. ${ }^{9}$ Makanan Indonesia juga banyak menggunakan selada seperti gado-gado, lalapan nasi goreng, dan lalapan pecel lele. ${ }^{10}$
Faktor lain yang mempengaruhi angka kejadian penyakit kecacingan adalah lingkungan yang menyokong untuk perkembangan STH yaitu kondisi tanah yang gembur dan lembab. ${ }^{11}$

Berdasarkan survei awal dengan cara menanyakan kepada pedagang selada di pasar di Kota Padang tentang daerah asal selada yang dijual, didapatkan suatu kesimpulan bahwa terdapat beberapa daerah perkebunan penghasil selada, yaitu Bukittinggi, Alahan Panjang dan Padang Panjang. Kondisi perkebunan yang jauh dari sumber air dan tempat $\mathrm{BAB}$, membuat petani $\mathrm{BAB}$ ditengah perkebunan, sehingga tanah tercemar oleh feses yang mengandung telur cacing. STH akan berkembang biak dengan baik pada tanah gembur dan lembab. Selada dapat ditanam pada berbagai jenis tanah, namun pertumbuhan yang baik akan diperoleh bila ditanam pada tanah gembur, lembab dan mengandung cukup bahan organik. Diasumsikan selada dan STH hidup dalam kondisi tanah yang serupa. Daun selada berposisi duduk sehingga kontak langsung dengan tanah, ${ }^{10}$ Keadaan ini memungkinkan telur STH akan mudah menempel pada daun selada yang berada dekat dengan lokasi BAB terutama pada bagian krop terluar dan ujung bagian selada.

Berbeda dengan sayuran lain, selada tidak pernah dimasak karena setelah dimasak rasanya menjadi agak liat. ${ }^{10} \mathrm{Hal}$ ini memungkinkan telur STH dengan mudah masuk ke dalam tubuh karena selada yang dikonsumsi tidak dicuci bersih

Menurut penelitian Nugroho dkk tahun 2010, terdapat kontaminasi telur STH sebesar $38,89 \%$ pada sayuran kubis/kol (Brassica oleracea) yang digunakan sebagai lalapan mentah pada warung makan lesehan di Kota Wonosari Gunung Kidul Yogyakarta. ${ }^{12}$ Berdasarkan hasil pemeriksaan telur STH pada lalapan (kemangi, kol, selada dan terong) di pasar tradisional, supermarket dan restoran di Medan didapatkan hasil bahwa selada yang dijual di pasar tradisional dan supermarket tidak memenuhi syarat kesehatan. Ditemukan telur Ascaris lumbricoides pada selada yang dijual di pasar tradisional dan ditemukan telur Tricuris trichiura pada selada yang dijual di supermarket. $^{13}$ 


\section{METODE}

Penelitian ini dilakukan di Laboratorium Parasitologi Fakultas Kedokteran Universitas Andalas. Jenis penelitian ini adalah deskriptif yang telah dilaksanakan pada September - Desember 2013. Pengambilan sampel dengan menggunakan teknik simple random sampling. Jumlah sampel dalam penelitian ini adalah 49 selada, 44 berasal dari pasar tradisional dan 5 berasal dari pasar modern. Khusus untuk pasar tradisional dibuat mapping pedagang terlebih dahulu. Semua populasi diinput kemudian dilakukan pelotingan untuk penentuan sampel. Bagian selada yang diteliti adalah 5 krop dari bawah. Bahan yang digunakan adalah selada keriting dan larutan $\mathrm{NaOH} 0,2 \%$. Alat yang digunakan adalah tabung sedimen, pipet tetes, centrifuge, rak tabung, mikroskop, obyek glass, ember, dan pinset. Prosedur kerja dimulai dengan merendam selada dalam larutan $\mathrm{NaOH} 0,2 \%$ selama 30 menit. Kemudian selada diangkat dan air sisa rendaman dimasukkan ke dalam tabung sedimentasi kemudian diamkan selama 1 jam. Setelah itu, ambil endapan sebanyak 10-15 ml lalu dicentrifuge dengan kecepan 1500 rpm selama 5 menit. Kemudian lakukan pemeriksaan mikroskopis dengan perbesaran 10-40 kali. Identifikasi STH dilakukan dengan menyesuaikan bentuk STH yang ditemukan dengan bentuk pada atlas parasitologi. Data disajikan dalam bentuk tabel distribusi frekuensi.

\section{HASIL}

Berdasarkan hasil penelitian tentang pemeriksaan Soil Transmitted Helminth (STH) pada sayuran selada yang dilakukan di Laboratorium Parasitologi Fakultas Kedokteran Universitas Andalas, didapatkan hasil sebagai berikut :

Tabel 1. Distribusi Frekuensi STH pada Sayuran Selada yang Dijual di Pasar Tradisional di Kota Padang

\begin{tabular}{ccc}
\hline Hasil pemeriksaan & Frekuensi & $\%$ \\
\hline+ & 32 & 73 \\
\hline- & 12 & 27 \\
\hline Jumlah & 44 & 100 \\
\hline
\end{tabular}

Berdasarkan tabel 1, dari 44 sampel yang diperiksa ditemukan STH positif sebanyak 32 (73\%) dan STH negatif sebanyak 12 (27\%).

Tabel 2. Distribusi Frekuensi STH pada Sayuran Selada yang Dijual di Pasar Modern di Kota Padang

\begin{tabular}{ccc}
\hline Hasil pemeriksaan & Frekuensi & $\%$ \\
\hline+ & 2 & 40 \\
\hline- & 3 & 60 \\
\hline Jumlah & 5 & 100 \\
\hline
\end{tabular}

Berdasarkan tabel 2, dari 5 sampel yang diperiksa ditemukan STH positif sebanyak 2 (40\%) dan STH negatif sebanyak $3(60 \%)$.

Tabel 3. Persentase Jenis STH yang Terdapat pada Sayuran Selada yang Dijual di Pasar Tradisional di Kota Padang

\begin{tabular}{ccc}
\hline Jenis & Frekuensi & $\%$ \\
\hline Telur Ascaris sp & 30 & 79 \\
Telur Cacing tambang & 2 & 5 \\
Larva Trichostrongylus & 6 & 16 \\
orientalis & & \\
\hline Jumlah & 38 & 100 \\
\hline
\end{tabular}

Berdasarkan tabel 3 didapatkan bahwa jenis STH terbanyak yang ditemukan pada sampel di pasar tradisional di Kota Padang adalah telur Ascaris $s p$ dengan frekuensi 30 (79\%), telur cacing tambang sebanyak 2 (5\%) dan larva Trichostrongylus orientalis sebanyak $6(16 \%)$.

Tabel 4. Persentase Jenis STH yang Terdapat pada Sayuran Selada yang Dijual di Pasar Modern di Kota Padang

\begin{tabular}{lcc}
\hline \multicolumn{1}{c}{ Jenis } & Frekuensi & $\%$ \\
\hline Telur Ascaris sp & 2 & 100 \\
Telur Cacing tambang & - & - \\
Larva Trichostrongylus & - & - \\
orientalis & & \\
\hline \multicolumn{1}{c}{ Jumlah } & 2 & 100 \\
\hline
\end{tabular}

Berdasarkan tabel 4, terlihat bahwa hanya telur Ascaris sp yang ditemukan pada sampel yang dijual di 
pasar modern. Tidak ditemukan cacing tambang maupun Trichostrongylus orientalis seperti yang ditemukan pada sampel dari pasar tradisional.

\section{PEMBAHASAN}

Berdasarkan tabel 1, ditemukan STH positif pada selada dari pasar tradisional sebanyak 32 (73\%) dari 44 selada yang diperiksa. Tingginya persentase ini dapat dipengaruhi oleh kontaminasi pasar. Selada di pasar tradisional diletakkan terbuka di baki sayur, di atas meja, atau kantong plastik besar atau karung, dan tidak jarang terletak sembarangan. Faktor lain yang mempengaruhi keberadaan STH pada selada seperti penggunaan pupuk organik yang berasal dari ternak hewan sebagai media penyuburan sayuran. Sama halnya seperti pada manusia, jika kotoran ternak tersebut mengandung telur STH, maka dengan mudahnya telur STH yang ada di dalam kotoran ternak yang digunakan sebagai pupuk akan berpindah ke daun selada yang kontak langsung dengan tanah.

Berdasarkan tabel 2, ternyata masih ditemukan STH pada selada dari pasar modern meskipun persentasenya lebih rendah daripada di pasar tradisional. Berdasarkan pengamatan, selada di pasar modern diletakkan di lemari berpendingin. Keberadaan STH pada selada dari pasar modern mungkin dapat disebabkan karena teknik pencucian selada yang tidak tepat. Selada yang dijual di pasar modern terlihat lebih bersih dan tidak ada tanah maupun pasir yang menempel karena sudah dicuci terlebih dahulu. Kemungkinan selada dicuci sekaligus dalam jumlah yang banyak pada sebuah ember. Hal ini memungkinkan tanah atau pasir terlepas dari daun selada namun STH dapat tetap terselip dan menempel diantara lembaran daun selada. Teknik pencucian sayuran yang benar adalah sayuran dicuci pada air kran yang mengalir, dicuci lembar perlembar, kemudian dicelupkan sebentar ke dalam air panas atau dibilas dengan menggunakan air matang sehingga STH yang mungkin melekat dapat terbuang bersama aliran air tersebut. ${ }^{14}$

Berdasarkan tabel 3, jenis STH yang ditemukan pada selada dari pasar tradisional adalah telur Ascaris $s p$, telur cacing tambang dan larva Trichotrongylus orientalis. Dominasi telur Ascaris sp pada penelitian ini disebabkan oleh sifat dari telur Ascaris sp yang tahan terhadap desinfektan kimiawi serta terhadap rendaman sementara di dalam berbagai bahan kimia seperti $\mathrm{NaOH}$ yang digunakan pada penelitian ini. Selain itu, telur dapat hidup berbulan-bulan di dalam air selokan dan tinja.

Telur Ascaris sp yang ditemukan pada penelitian ini tidak bisa dipastikan adalah spesies Ascaris lumbricoides. Genus ascaris terdiri dari beberapa spesies yaitu Ascaris lumbricoides dengan hospes definitifnya adalah manusia, Ascaris suum yang lazim terdapat pada babi namun terkadang dapat menyebabkan creeping eruption pada manusia dan Ascaris vitulorum yang terdapat pada sapi, kambing maupun domba. ${ }^{2}$ Telur dari spesies Ascaris tersebut tidak dapat dibedakan melalui pemeriksaan langsung dengan mikroskop karena mempunyai rentang ukuran yang sama dan bentuk yang sama.

Kemungkinan telur ascaris yang ditemukan pada penelitian ini adalah telur Ascaris lumbricoides, atau Ascaris suum, atau Ascaris vitulorum, bahkan juga mungkin berasal dari Toxocara canis atau Toxocara cati. Toxocara canis biasanya terdapat pada anjing dan Toxocara cati terdapat pada kucing. Kedua spesies ini berasal dari famili yang sama dengan Ascaris lumbricoides yaitu famili Ascaridida. Bentuk telur toxocara mirip dengan bentuk telur Ascaris lumbricoides setelah dibuahi karena kedua spesies ini berasal dari famili yang sama dan genus berbeda. Namun keduanya tetap dapat menyebabkan gejala klinis pada manusia jika terinfeksi dalam jumlah banyak dan daya tahan tubuh rendah. ${ }^{2}$

Telur cacing tambang hanya ditemukan pada 2 dari 44 selada. Frekuensi yang sedikit ini dapat disebabkan karena faktor jenis tanah dan suhu. Berbeda dengan STH lainnya, telur cacing tambang dapat tumbuh optimum pada lingkungan yang mengandung pasir karena pasir memiliki berat jenis yang lebih besar dari pada air sehingga telur-telur akan terlindung dari sinar matahari. Suhu juga merupakan faktor yang mempengaruhi pertumbuhan telur cacing tambang. Suhu optimum pertumbuhan cacing tambang yaitu $35^{\circ} \mathrm{C}$, namun suhu daerah perkebunan selada lebih dingin yaitu berkisar antara $15^{\circ} \mathrm{C}-25^{\circ} \mathrm{C}$ sehingga tidak baik untuk pertumbuhan telur cacing tambang. Namun beberapa telur cacing tambang mempunyai kemampuan adaptasi tinggi 
sehingga dapat tetap bertahan meskipun perkembangannya tidak optimal. ${ }^{15}$

Telur cacing tambang pada penelitian ini dapat berasal dari cacing tambang pada manusia yaitu Necator americanus dan Ancylostoma duodenale, karena bentuk telur keduanya tidak dapat dibedakan melalui pemeriksaan langsung dengan mikroskop, tetapi dapat dibedakan dengan cara Harada-Mori. Selain itu, telur cacing tambang dapat juga dapat berasal dari cacing tambang pada kucing dan anjing yaitu Ancylostoma braziliense, Ancylostomaceylanicum dan Ancylostoma caninum. ${ }^{2}$ Jenis STH lain yang ditemukan pada selada dari pasar tradisional yaitu larva Trichostrongylus orientalis. Telurnya jarang ditemukan karena telur akan menjadi larva dalam waktu 24 jam. ${ }^{2}$

Berdasarkan tabel 4, hanya telur Ascaris sp yang ditemukan pada selada dari pasar modern. Tidak ditemukan telur cacing tambang dan larva Trichostrongylus oriental karena, selada yang dijual dipasar modern diletakkan pada lemari berpendingin khusus. Telur cacing tambang berkembang pada suhu $35^{\circ} \mathrm{C}$, sehingga tidak akan berkembang jika diletakkan pada suhu dingin begitu juga dengan larva Trichostrongylus oriental. $^{15}$ Memang sangat kecil kemungkinan ditemukannya telur cacing tambang dan larva Trichostrongylus oriental dengan jumlah sampel yang sedikit yaitu hanya 5 selada dari pasar modern.

Hasil penelitian ini mirip dengan penelitian sebelumnya yang dilakukan di Medan tahun 2012. Pada penelitian tersebut dilakukan pemeriksaan telur cacing pada selada yang dijual di pasar tradisional, supermarket dan restoran di Kota Medan dengan hasil positif ditemukan telur STH. Diduga akibat kontaminasi juga berasal dari teknik pecucian kurang tepat. Telur Ascaris lumbrocoides adalah yang paling banyak ditemukan. $^{13}$

Penelitian ini dapat menjelaskan kepada kita bahwa selada sangat berpotensial untuk penularan penyakit yang disebabkan oleh STH. Maka dalam hal ini sangat diperlukan upaya pencegahan. Untuk menghindari agar STH yang terdapat pada sayuran selada tidak masuk ke tubuh, maka tindakan preventif yang dapat dilakukan yaitu pencucian selada dengan air mengalir karena dapat menghilangkan STH yang menempel pada daun selada sebanyak $94 \%{ }^{16}$

\section{KESIMPULAN}

Berdasarkan penelitian ini, penulis dapat menyimpulkan beberapa hal, yaitu:

1. STH postif pada selada dari pasar tradisional yaitu 32 dengan persentase $73 \%$.

2. STH postif pada selada dari pasar modernl yaitu 2 dengan persentase $40 \%$

3. Sebagian besar dari STH yang ditemukan pada penelitian ini adalah telur ascaris sp kemudian menyusul larva Trichostrongylus orientalis dan telur cacing tambang.

\section{UCAPAN TERIMA KASIH}

Penelitian ini dapat berlangsung berkat bimbingan dari dari staf Laboratorium Parasitologi Fakultas Kedokteran Universitas Andalas.

\section{DAFTAR PUSTAKA}

1. Depkes RI. Pedoman Umum Program Nasional Pemberantasan Cacingan di Era Desentralisasi. Jakarta: Depkes RI; 2004.

2. Supali T, Margono SS, Abidin SAN. Nematoda usus. Dalam: Sutanto I, Ismid IS, Sjarifuddin PK, Sungkar S.Ked). Cetakan ke-4. Jakarta: Balai penerbit FKUI; 2008. hIm.6-29.

3. Direktorat Jendral Pemberantasan Penyakit Menular-Penyakit Lingkungan. Profile PPM-PL tahun 2004. Dalam: Salbiah. Hubungan karakteristik siswa dan sanitasi lingkungan dengan infeksi cacingan siswa sekolah dasar di Kecamatan Medan Balewang.Tesis. 2008.

4. Antara. Cacingan, Sumatera Barat nomor satu tingkat nasional (diunduh pada 25 Juni 2013). Tersedia dari URL: HYPERLINK http://www.antaranews.com/berita/2795 30/cacingan-sumatera-barat-nomorsatu-tingkat-nasional. 2011.

5. Fitri J, Saam Z, Hamidy MY. Analisis Faktor-faktor Risiko Infeksi Kecacingan Murid Sekolah Dasar di Kecamatan 
Angkola Timur Kabupaten tapanuli

Selatan Tahun 2012. Jurnal IImu

Lingkungan. 2012; 6(2):146-161.

6. Winita R, Mulyati, Astuty $H$. Upaya Pemberantasan Kecacingan di Sekolah Dasar. Jurnal Makara. 2012; 16(2):6571.

7. Gillespie $\mathrm{SH}$, Piarson RD. Principles and practice of clinical parasitology. USA: British Library; 2001. hlm. 561-6.

8. Lingga L. Cerdas memilih sayuran. Jakarta: AgroMedia pustaka; 2010. hlm. 30.

9. Haryanto E, Suhartini T, Rahayu E, Sunarjono H. Sawi dan selada.Cetakan ke-7. Jakarta: Penebar Swadaya; 2007.

10. Sunardjono H. Bertanam 30 jenis sayuran. Jakarta: Penebar Swadaya; 2010. hlm. 87-92.

11. Pracaya. Bertanam sayur organic.Cetakan ke-2. Jakarta: Penebar swadaya; 2010. hlm. 63-5.

12. Nugroho C, Djanah SN, Mulasari SA. Identifikasi kontaminasi telur nematoda usus pada sayuran kubis (Brassica oleracea) warung makan lesehan

Wonosari Gunungkidul Yogyakarta tahun 2010. Jurnal Fakultas Kesehatan Masyarakat Universitas Ahmad Dahlan. 2010; 4(1): 67-75.

13. Purba SF, Chahaya I, Marsaulina I. Pemeriksaan Escherichia coli dan larva cacing pada sayuran lalapan kemangi (Ocimum basilicum), kol (Brassica oleracea L. var.capitata. L.), Selada (Lactuca sativa L.), Terong (Solanum melongena) yang Dijual di Pasar Tradisional, Supermarket dan Restoran di Kota Medan tahun 2012. Medan, Universitas SumateraUtara. Tesis. 2012.

14. Depkes RI. Kumpulan Modul Kursus Hygiene Sanitasi Makanan \& Minuman, Depkes RI, Jakarta; 2010.

15. Sandjaja B. Helmintologi Kedokteran. Jakarta: Prestasi Pustaka; 2007.

16. Yuwono A. Efektifitas Teknik Pencucian terhadap Penurunan Jumlah telur Nematoda Usus pada Sawi. Semarang, Universitas Diponegoro; 2009. 